\title{
THE GROUNDS FOR METROPOLITAN COOPERATION. A CASE STUDY OF THE GDAŃSK-GDYNIA-SOPOT METROPOLITAN AREA
}

\author{
PODSTAWY WSPÓŁPRACY METROPOLITALNEJ. \\ PRZYKŁAD OBSZARU METROPOLITALNEGO GDAŃSK-GDYNIA-SOPOT
}

\begin{abstract}
NR DOI: $10.25167 / \mathrm{sm} 2018.031 .04 \quad$ s. $53-67$
ABSTRACT: The process of institutionalization of metropolitan cooperation within the metropolitan area around Gdańsk has been the subject of a debate with the participation of local representatives of various sectors. Currently, the main entity carrying out activities on a metropolitan scale is the Gdańsk-Gdynia-Sopot Metropolitan Area Association. It has been responsible for a series of bottom-up projects, implementation of the Integrated Territorial Investments mechanism, as well as lobbying towards establishing a metropolitan union in Pomeranian Voivodship. The article describes the current conditionings that seem to be the most important for the spatial extent and objects of the cooperation in the context of the foregoing metropolitan discourse.
\end{abstract}

KEY WORDS: metropolitan governance, multi-level governance, Gdańsk-Gdynia-Sopot Metropolitan Area, Integrated Territorial Investments

ABSTRAKT: Proces instytucjonalizacji współpracy metropolitalnej na terenie obszaru metropolitalnego kształtującego się wokół Gdańska od początku transformacji ustrojowej stanowi przedmiot lokalnej debaty z udziałem przedstawicieli różnych sektorów. Obecnie najważniejszym podmiotem realizującym działania w skali metropolitalnej jest Stowarzyszenie Obszar Metropolitalny Gdańsk-Gdynia-Sopot, odpowiedzialne za szereg oddolnych projektów, wdrażanie mechanizmu Zintegrowanych Inwestycji Terytorialnych, a także lobbing mający doprowadzić do uchwalenia ustawy poświęconej obszarowi. W artykule uwzględniono kontekst ostatnich kilkunastu lat kształtowania się współpracy, jak również opisano aktualne uwarunkowania, które będę miały decydujące znaczenie dla jej przedmiotu i zasięgu przestrzennego.

SŁOWA KLUCZOWE: zarządzanie metropolitalne, zarządzanie wieloszczeblowe, Obszar Metropolitalny Gdańsk-Gdynia-Sopot, Zintegrowane Inwestycje Terytorialne

\section{Introduction}

The main aim of the paper is to present the most significant factors which have recently influenced the process of building-up metropolitan cooperation within the

\footnotetext{
" University of Gdańsk, Faculty of Oceanography and Geography, Department of Socio-Economic Geography, ul. Jana Bażyńskiego 4, 80-309 Gdańsk, e-mail: rafal.gajewski@ug.edu.pl
} 
borders of the Gdańsk-Gdynia-Sopot Metropolitan Area in the context of the European Union's and national policies towards metropolitan areas. The Gdańsk-Gdynia-Sopot Metropolitan Area Association (the GGS MA) was established in 2011 and currently comprises 57 local governments. It is considered to be one of the most successful examples of metropolitan cooperation in Poland. Since 2015 it has been responsible for the implementation of the European Union Integrated Territorial Investment financial instrument. It had already started to deliver some bottom-up actions on a metropolitan scale before that. Despite the wide range of current initiatives, any success of further integration depends on some key factors, which will be taken into consideration in the paper. The institutional perspective is the starting point for the analysis.

\section{Multidimensionality of metropolitan policies}

City-regions and metropolitan areas remain constructs that should be perceived through the prism of economic, political and spatial phenomena (d'Albergo \& Lefèvre, 2018) and require unusually high adaptability across different disciplines (Barnett \& Bridge, 2016). Neuman and Hull claimed that "today, the debates surrounding regional questions are more complex than ever in many dimensions. They are multidisciplinary and multi-scalar, and the phenomena under analysis are themselves more complex, as evidenced by an abundance of empirical and theoretical research in the last decades" (Neuman \& Hull, 2009: 777). Regardless of the research perspective, this statement remains extremely prevailing.

The role of public authorities in constructing metropolitan as well as regional policies and governance structures has been the subject of multiple research for an extended period of time. While analysing selected research in this area carried out over the last 20 years, several regularities can be observed. At the beginning of this period, cityregionalism was gaining in momentum (e.g. Mcleod \& Goodwin 1999; Herrshel \& Newman 2002). The necessity of new scales in providing public policies was highlighted explicitly with great attention paid to the term of re-scaling developed by Brenner (e.g. 1999, 2001). City-regions then became new significant centers of governance and actions taken by the state as well as non-public actors. Consequently, in further analyses researchers were trying to describe the structure and capture factors that determine how city-regions operate. Depending on the approach, we can find them among studies concerning: historical backgrounds that influence current phenomena and processes (Combees, 2014; Deas, 2013; Keating, 2017), ways of governance as well as relations within metropolitan areas (Governing cities through regions..., 2016; Harrison \& Heley, 2015; The European Metropolises..., 2011), metropolitan citizenship and identity (Kübler 2018; Vallbé et al., 2018) and the role of private actors and investment projects in regional and metropolitan development or spatial integration (Dembski, 2015; Harrison, 2013).

Despite the growing spectrum of problems already described in research, many issues related to the formation and functioning of city-regions, or metropolitan areas, 
remain insufficiently recognized or only gain a place on the research agenda. One of them, important in the context of the subject of this study, is the issue of interdependencies between metropolitan and regional as well as national levels of governance with regard to shaping policies at the first of the indicated levels (Jonas \& Moisio, 2018). The other, which I also refer to in the article, is the political dimension of city-regionalism. By that I mean it is the matter of which actors and in what ways they affect socioeconomic processes occurring in specific territories. Recent studies concerning the role of public-private relations and governance networks, as well as discursive construction of metropolitan scale, uncover the multiplicity of paths by means of which, through the actions of numerous entities (especially those from the public sector), metropolitan space is created (d'Albergo et al., 2018; Fricke \& Gualini, 2018; Nelles et al., 2018).

Despite the growing number of case studies concerning city-regions and metropolitan areas located in Western European and North American countries (e.g., Herrschel, 2016; Kauffmann, 2016; Ziafati Bafarasat, 2018), not much attention has been focussed on the Central and East European countries and comparative studies including their regions and metropolitan areas. To some extent, they still seem to be on a side note of interest as one of "the world of other places beyond Western common law legal regimes" (Delaney 2016: 1), although, at the same time, one cannot underestimate the value of both theoretical and empirical in-depth analysis concerning the processes of development of the metropolitan functions, institutional cooperation and socio-economic phenomena within the functional area of the Polish biggest cities (e.g. Danielewicz, 2013; Lackowska, 2009; Suliborski \& Przygodzki, 2010; Zuzańska-Żyśko, 2016).

\section{Historical conditionings and institutional framework for metropolitan governance in Poland}

To begin with, it is worth presenting some critical historical and institutional conditionings which significantly affect further considerations. Over the $20^{\text {th }}$ century, it was difficult to talk about the state's and local authority's policies towards regions and the most significant cities. Poland regained independence in 1918 as a result of the end of the Great War. Building a new country started over the following years, but the whole effort was undermined by the outbreak of the Second World War.

The effects of the war, unsurprisingly, turned out to be disastrous for the country and the biggest Polish cities. Therefore, after the war the primary task of the authorities was to rebuild cities rather than to create permanent foundations for their development. What was particularly notable was that these years were enormously costly, in social terms. It is starkly illustrated when we compare the population of Polish cities in the crucial historical moments (Table 1).

After the Communist takeover, any attempts aimed at giving independence to local authorities were virtually impossible. Under the system of unitary power, administration and property, the cities had lost their subjectivity - they were no longer the subject of separate rights and obligations, and they served the sole purpose of carrying that 
Population changes in Polish cities

\begin{tabular}{|l|c|c|c|c|c|c|r|c|}
\hline \multicolumn{1}{|c|}{ City } & 1921 & 1939 & $1945 / 46$ & 1950 & 1970 & 1990 & \multicolumn{1}{c|}{2008} & 2018 \\
\hline Warszawa & 936,000 & $1,295,000$ & 377,000 & 804,000 & $1,316,000$ & $1,656,000$ & $1,709,000$ & $1,758,000$ \\
\hline Kraków & 183,000 & 259,000 & 298,000 & 344,000 & 590,000 & 751,000 & 754,000 & 766,000 \\
\hline Łódź & 452,000 & 672,000 & 496,000 & 620,000 & 763,000 & 848,000 & 747,000 & 693,000 \\
\hline Wrocław & $528,000^{\mathrm{a}}$ & 625,000 & 170,000 & 309,000 & 526,000 & 643,000 & 632,000 & 638,000 \\
\hline Poznań & 169,000 & 274,000 & 267,000 & 321,000 & 472,000 & 590,000 & 557,000 & 539,000 \\
\hline Gdańsk & $206,000^{\mathrm{b}}$ & 250,000 & 115,000 & 195,000 & 366,000 & 465,000 & 455,000 & 464,000 \\
\hline Szczecin & $254,000^{\mathrm{c}}$ & 383,000 & 26,000 & 179,000 & 338,000 & 413,000 & 406,000 & 405,000 \\
\hline Katowice & $113,000^{\mathrm{b}}$ & 134,000 & 107,000 & 225,000 & 305,000 & 367,000 & 309,000 & 297,000 \\
\hline
\end{tabular}

a data for 1919; ${ }^{\text {b }}$ data for 1924; ${ }^{\text {c }}$ data for 1925.

Source: own work, Jakub Szlachetko.

unitary state power and state administration" (Niziołek, 2008: 54). While in Western European countries there was a debate raging over policies concerning functional urban areas, in Poland no steps in this direction were taken. The growth processes of metropoles observed in Poland today started in Western Europe as far back as the 1960s and the 1970s (Kaczmarek \& Mikuła, 2007). What was particularly noteworthy was that the communist years were costly not only in terms of the absence of relevant activities concerning the metropoles, but also - and almost certainly of no less importance - in the social dimension. The Communism's last decade alone (1980-1989) cost Poland more than a million of its best and brightest, who left the country through emigration (Heihnsohn, 2014).

At the beginning of the political transformation, it was difficult to expect that the legislature would take the regions' or cities' problems into account during work on the reformation of the local government system. At that time, it was more important to solve the most immediate and pressing problems (Kowalewski, 1991), which first of all meant the necessity of breaking the existing monopolies in the contemporaneous system: the party monopoly, monopoly of unitary state power, monopoly of state property, financial monopoly, and finally - the state administration monopoly, excluding any local autonomy (Regulski, 1991). Unlike the Czech Republic, Slovakia and Hungary, also the issue of the size of the government had not been widely discussed in Poland, nor had any significant changes been introduced (Swianiewicz, 2002). However, while the lack of institutional solutions development in the last decade of the $20^{\text {th }}$ century can be ultimately forgiven (considering the conditioning mentioned above), the lack of or little concrete action in this field in the first decade of the $21^{\text {st }}$ century is rather more unforgivable.

The current territorial division of the country was established in 1998 and includes three levels of local government: communes, counties and voivodships (regions). There 
are 2,478 communes, 380 counties and 16 voivodships. In 2017, the law which introduced the first metropolitan government in Poland was implemented. Against such a backdrop, Integrated Territorial Investment (ITI) - the instrument of territorial development implemented by the EU policy - seemed to be a great opportunity to improve governance within borders of metropolitan areas as well as between different levels of local authorities. It reflects the EU Territorial Cohesion Policy and imposes specific requirements on local governments and NGOs from each territory, as well as the national government, in return for the possibility to apply for support for infrastructure and social projects. In order to adjust undertaken projects to real needs and the expectations of the general population, ITIs could be managed by organizations created within the cooperation of local government units: unions, partnership agreement, associations or companies founded jointly by local government units. ${ }^{1}$ Partnerships between local governments, business institutions and NGOs are the sine qua non condition for the implementation of projects (Integrated Territorial Investment..., 2014; Programowanie perspektywy finansowej..., 2017: 227-231). The budget of each identified action is at least a few times greater than the proceeds obtained by the associations and unions from their membership fees.

Despite the scale of endeavours that have been carried out within ITIs and the positive symptoms of cooperation between local governments, there are many uncertainties about how the cooperation within functional urban areas will look like after 2023 (by this time all the projects will have had to be completed). Reaching beyond this perspective and looking for the concept of appropriate application of the experience gained pose a real challenge to public authorities and their partners.

\section{The process of institutionalization of cooperation within borders of the Gdańsk-Gdynia-Sopot Metropolitan Area ${ }^{2}$}

The Gdańsk-Gdynia-Sopot Metropolitan Area Association consociates 57 local governments (communes, counties and cities with county rights; Map 1). It has been operating under this name since 2015. Its previous name was “The Gdańsk Metropolitan Area Association”. Currently, it also has nine supporting members (including municipal companies, Gdańsk Lech Walesa Airport, and Olivia Business Centre - the largest office complex in the region), who have an advisory voice regarding the activities carried out by the organization.

\footnotetext{
1 In effect, 9 ITIs in Poland operate on the basis of partnership agreements, and 8 in the form of associations of local government units (Krukowska, Lackowska 2017: 97).

2 I also describe the process of institutionalization of cooperation as well as present in more detail actions of the authorities of The Gdańsk-Gdynia-Sopot Metropolitan Association aimed at establishing a metropolitan union in the Pomorskie Voivodship in the article: "W kierunku związku metropolitalnego w województwie pomorskim” [in:] Dolnicki B. (ed.) (2018) Organizacja i funkcjonowanie aglomeracji miejskich, Wolters Kluwer Polska, Warszawa, pp. 97-108.
} 


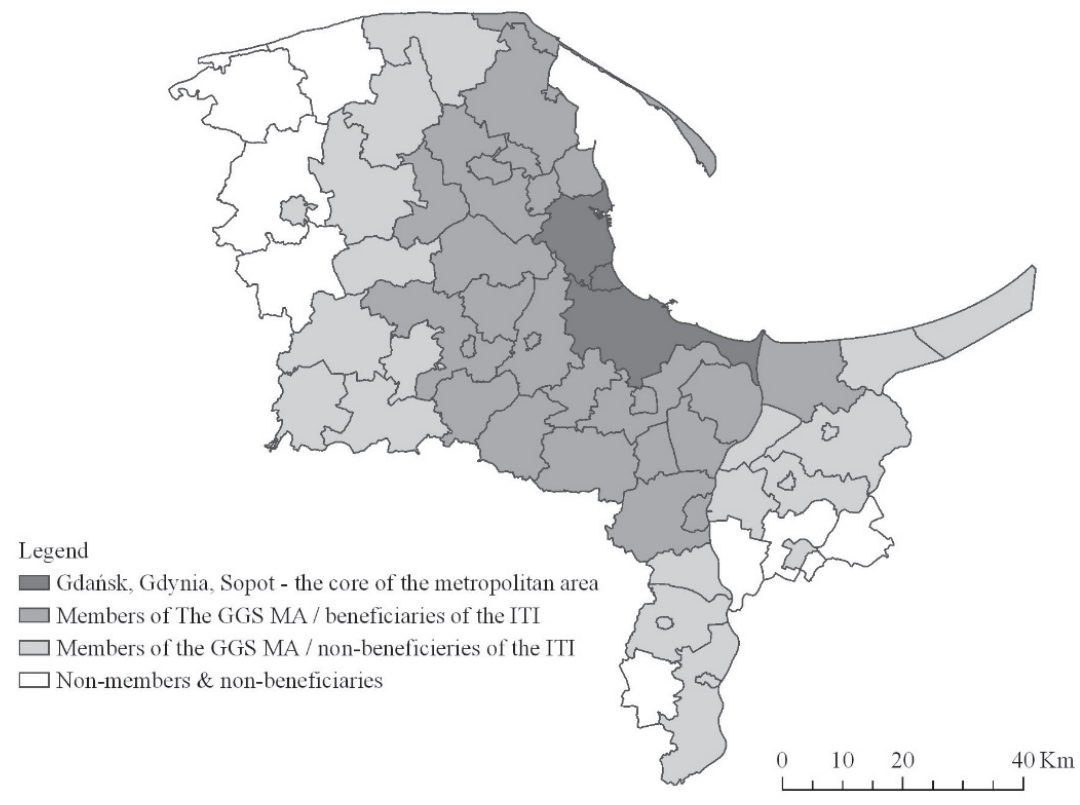

Map 1. Members of The Gdańsk-Gdynia-Sopot Metropolitan Area Association and beneficiaries of the ITI mechanism. Spatial extent consistent with the Gdańsk-GdyniaSopot Metropolitan Areas Spatial Development Plan

Source: own work on the basis of www.metropoliagdansk.pl

The Association was established in September 2011 by 29 local authorities located south and west of Gdańsk. Gdynia, Wejherowo as well as several other communities from the northern part of the area joined the Association in 2015. The existence of a one-metropolitan structure, operating in the statutory formula of the association, was a condition set by the central government for obtaining the possibility of implementing the Integrated Territorial Investment mechanism. Building-up a one-metropolitan institution had not been possible before without this kind of financial incentive.

The issue of metropolitan cooperation within the area around Gdańsk has been discussed since the beginning of the state structural transformation. A number of activities were also undertaken to improve the performance of public services. It is worth mentioning here the most important ones (see more: Czepczyński, 2014). The "Reda\&Chylonka Valley" Municipal Union was established in 1991 by the municipalities of Gdynia, Reda, Rumia, Wejherowo, and Kosakowo (later Sopot, Wejherowo and Szemud joined the Union). The main tasks of the union are water supply and waste management. At the beginning of the 1990s, the local authorities opened a debate concerning delimitation and creation of the Gdańsk Metropolitan Group, which was supposed to be responsible, among other things, for creating a metropolitan economic strategy, preparing a joint promotion program, coordinating spatial development plans, integrating public transport and coordinating activities in the field of environmental 
protection. Then, after the administrative reform of the country in 1998, The Metropolitan Council of the Gulf of Gdansk was formed in 2003. It included representatives of Gdańsk, Gdynia, Sopot, Pruszcz Gdanski, Żukowo, Kolbudy, Kosakowo, Reda, Rumia and Wejherowo and the Marshal of the Pomeranian Voivodship. One of the main goals of this informal body was to accelerate the integration of the public transport system. Significant effects of the work of the Metropolitan Council were consultations and opinions sought on the spatial development project of the metropolitan area prepared by the Marshal's Office of the Pomeranian Voivodeship. ${ }^{3}$

The issues of the metropolitan development were also not indifferent to the representatives of the scientific community. In 2005, the "Tri-City Manifesto" was published. Its authors called for a wide public debate about the creation of the Gdańsk metropolis. The starting point of the document was the thesis that without a strong institutionalized metropolitan government, the Tri-City would develop slower than other large Polish cities. The direct effect of the publication of the "Tri-City Manifesto" was the establishing of the Social Committee for the Tri-City Metropolis, with the participation of representatives of science and business. Two years later, the Metropolitan Transport Union of the Gulf of Gdańsk was registered. Its members are Gdańsk, Gdynia, Sopot, Żukowo, Kolbudy, Pruszcz Gdański, Reda, Rumia, Kosakowo, Luzino and Wejherowo). The union is tasked with integrating various collective transport systems by negotiating a common tariff, sales and ticket control.

On 13 September 2011, representatives of 15 communities from the northern part of the metropolitan area under the leadership of Gdynia signed a letter of cooperation under the partnership agreement of "NORDA". The agreement aimed to implement the Northern Ring Road of the Tri-City Agglomeration and to perform public tasks in the fields of tourism and education. Two days later, on 15 September 2011, the Founding Meeting of the Gdańsk Metropolitan Area Association was held, in which 29 local governments declared their willingness to belong to the organization. Over time, The Gdańsk Metropolitan Association changed its name into The Gdańsk-Gdynia-Sopot Metropolitan Area Association and expanded its activities both spatially and through the broader scope of actions. Nevertheless, despite building-up one metropolitan structure that covers the whole metropolitan area, the NORDA partnership agreement still formally exists and in recent years undertook actions promoting the tourist offer of its members (there are currently 23 of them).

\section{The scope of activities of The Gdańsk-Gdynia-Sopot Metropolitan Area Association}

The most important aim of The Gdańsk-Gdynia-Sopot Metropolitan Area Association is the promotion of cooperation and the coordination of the activities of all the

\footnotetext{
3 Source: http://www.metropoliagdansk.pl/co-robimy/inicjatywy-metropolitalne/inicjatywy-metropolitalne-1990-2011/.
} 
entities at the metropolitan arena: local governments and national government agencies as well as science, business, media, and non-governmental organizations. ${ }^{4}$ On the one hand, the Association acts as the Integrated Territorial Investment Union and supports the implementation of projects financed from the EU funds. On the other, it identifies activities carried out by individual local governments, which are possible to implement in different parts of the metropolitan area. The partnership also established, in 2015 and 2016, the strategic documents which deal with key issues concerning its development: Gdańsk-Gdynia-Sopot Metropolitan Area Development Strategy by 2030, a spatial development plan for the metropolitan area, Transport and Mobility Strategy, as well as a Low-Carbon Economy Plan.

When it comes to the ITI financial instrument, the Association coordinates the process of implementation of projects of ca. quarter of a billion EUR financed from the regional operational programme. The second group of projects - with a total budget more prominent than a half billion EUR - is financed from national programmes. Projects are divided into four thematic areas: transport and mobility, environment and energy, economic development and social development. Among them are: creation of a coherent network of nodes integrating transport systems (it is planned to revitalize the existing infrastructure, as well as build a new one), creating The Metropolitan Bike System as an element of improving the access to the aforementioned transport hubs and promoting the active mobility; thermo-modernization of residential and public buildings, an integrated program of cooperation of business incubators, as well as science and technology parks, a social and professional training system or a care program for the elderly.

Previous experience shows that realizing bottom-up projects without any outward incentives is possible, albeit a lot more demanding for all the entities involved. Indeed, there are examples of successful activities. The first of them is joint public procurement. The purchasing group was founded in 2012 and is currently being created by 27 municipalities together with their organizational units, cultural and educational institutions, and municipal companies. Purchases include electricity, natural gas, fuel for local authority vehicles, heating oil, postal services, and ballot boxes. Thanks to the group, local governments achieved savings of between 25-30\% compared to list prices. Another project is the integration of information and promotional activities around participatory budgets in different municipalities. One important event in the area of promotion of tourism is the annual "Enjoy the metropolis. A half-price weekend". It aims to encourage the residents of the metropolis to actively spend their free time and explore the region's attractions.

\footnotetext{
${ }^{4}$ According to $\$ 6$ point 1 and 2 of the Statute, the Association's goals are, among others: "harmonious, socio-economic development of communes and counties of the Metropolitan Area" and "common shaping and integration of the most important policies affecting the quality of life of the residents of the Metropolitan Area" (Statut Stowarzyszenia Obszar Metropolitalny Gdańsk-Gdynia-Sopot uchwalony dn 13 kwietnia 2015 r., ze zm. z dn. 8 czerwca 2017 r. / Statute of The Gdańsk-Gdynia-Sopot Metropolitan Area Association passed on 13 April 2015, amended on 8 June, 2017).
} 
In summary, the process of institutionalization of cooperation within the borders of the Gdańsk-Gdynia-Sopot Metropolitan Area would have been demonstrably slower and less prosperous without the ITI mechanism. Narrower competences, and thus responsibilities of local governments associations, often have a positive effect on the willingness of local governments to begin bottom-up cooperation, but in a long-term perspective - it can lead to a lack of real action undertaken by these entities. Even though the local governments became substantial beneficiaries of the ITI mechanism, a future model of cooperation should not be described as obvious. In some measure, this pendency can be described on the basis of the analysis of local authorities engagement in activities heading to establishing a metropolitan union - the legal structure that can be created through national law.

\section{Actions of the authorities of The Gdańsk-Gdynia-Sopot Metropolitan Association aimed at establishing a metropolitan union}

On 9 October 2015, the first "metropolitan law" was passed in Poland. The act covering metropolitan unions entered into force on 1 January 2016, but due to the lack of appropriate regulations of the Council of Ministers, it was not implemented. In 2017, this law was replaced by regulations dedicated directly to just one metropolitan area - Górnośląsko-Zagłębiowska Metropolia with Katowice as its capital city. ${ }^{5}$ The metropolitan union is a different form of cooperation between local authorities in comparison to a current association, communal unions and partnership agreements. Among the obligatory statutory tasks of the metropolitan union are spatial planning; integration and coordination of public transport, strategic, development and policies of promotion. The metropolitan union can also perform other public tasks on the basis of additional agreements with local government units and national government agencies.

Establishing a metropolitan union within the territory of Gdańsk-Gdynia-Sopot Metropolitan Area would provide more than 170 million PLN per annum from the central level to the budget of the union. Over seven years it has been an amount equivalent to the sources dedicated to the implementation of the ITI mechanism. Taking into consideration the fact that the future of the ITI is unknown, setting-up a metropolitan

${ }^{5}$ Respectively: The Metropolitan Unions Law of 9 October 2015 (Journal of Laws of the Republic of Poland 2015, pos. 1890) and The Śląskie Voivodship Metropolitan Union Law (Journal of Laws of the Republic of Poland 2017, pos. 730). Thirteen communities from the forty-one current members of the GórnośląskoZagłębiowska Metropolia were associated in the Metropolitan Communal Union of Upper Silesia between 2007 and 2017. First and foremost, it used to organise and manage public transport within the area (see: The list of communal unions by the Ministry for Internal Affairs and Administration, as of September 30, 2018). The other entity responsible for the implementation of the EU Integrated Territorial Investment mechanism has been The Association of Communities and Poviats of the Central Subregion, established in 2013. To see more about the genesis and current conditions of metropolitan cooperation in Silesia, e.g., Pyka, 2016; Zuzańska-Żyśko, 2013; Zuzańska-Żyśko, 2016. 
union could protect the integrity of current metropolitan activities and outcomes of projects that have been realized.

In this context, it is worth discussing the activities of the authorities of the GGS MA and its representatives that were conducted as a consequence of the passing of the metropolitan law in 2015, as well as the dedicated regulation for the Silesia Metropolis. Soon after the first of these regulations were passed (in October 2015), the General Assembly of the GGS MA Members was held. ${ }^{6}$ During the proceedings, the possibilities and chances of establishing a metropolitan union were discussed. Except the voices expressly supporting the setting-up of the union, the voices of the municipalities lying outside the core of the area, uncertain about the actual benefits and their influence of union's policies, were visible. The next General Assembly was held in June 2016. Representatives of 45 local governments at that time supported the idea of establishing a union, by way of a resolution, and expressed their readiness to start negotiations on this matter with the Ministry of Interior Affairs. Despite the negative approach from the national government and two negative answers from the Ministry mentioned above, the topic of the metropolitan union has not disappeared from the agenda of the GGS MA. In August 2017, during the General Assembly meeting, another discussion was held on this topic. It was also attended by members of parliament from different parties to encourage them to promote joint lobbying in favour of the metropolitan union in Pomeranian Voivodeship.

Then, in January 2018, The Dziennik Battycki (a newspaper) in partnership with Olivia Business Centre and the GGS MA organized the first in a series of debates with the aim of creating a public discourse around the need for integrating metropolitan activities and, above all, establishing a metropolitan union in the Pomeranian Voivodeship. The climax of the debate was the signing of the declaration of support for this initiative by local authorities. It is worth noticing that during the discussion the Mayor of Gdynia publicly expressed his support for establishing a metropolitan union in the Pomeranian Voivodeship for the first time. The real involvement of the two largest cities within the area in activities towards creating a union could certainly facilitate lobbying and an information campaign directed at residents, and local government officials. In the following months, further debates concerning: transport and mobility (February 2018), competitiveness (April 2018) and quality of life (June 2018) took place. Also, press articles appear regularly in The Dziennik Battycki as part of the "Metropolis in Pomerania" series.

The pursuit of establishing a metropolitan union in the Pomeranian Voivodeship is indicated, next to the implementation of the Integrated Territorial Investment mechanism, as the primary goal of the MA Association. Either in official statements or announcements addressed to the public, it is often outlined that the entire local government unanimously supports the idea of establishing the metropolitan union

\footnotetext{
${ }^{6}$ Data collected on the basis of the minutes of the meetings of the General Assembly of Members and meetings of the Board of the Association, as well as information available on the website www.metropoliagdansk.pl and Facebook.
} 
and that everyone is entirely convinced of the rationality of such a solution. Therefore, although the number of activities carried out by the GGS MA should be assessed positively, some doubts arise when it comes to the active participation in the process of all or a distinctive majority of local governments. The spatial illustration of the level of involvement of local government units' authorities in the aforementioned activities (three General Assemblies of the GGS MA Members and signing of the declaration of support during the first debate in the series of debates organized by The Dziennik Battycki; Map 2) allows us to observe several consistencies with reference to the scale of involvement of individual local governments. First of all - stronger support in the core and weaker in the northern and south-eastern parts of the area. In addition, the most substantial support is visible among local authorities that have been engaged in building-up the GGS MA, and previously, The Gdańsk Metropolitan Area Association for many years. Furthermore, the Area of Kashubia (located west of Gdańsk) is a big beneficiary of the investment in the Pomeranian Metropolitan Railway. Proportionally weaker support from northern communities can be combined with a historical background of inter-municipal cooperation and the existence of the NORDA partnership agreement around Gdynia.

Importantly, the topic of establishing a metropolitan union in the Pomeranian Voivodeship remains on the agenda of the activities of the Association's authorities,

Legend

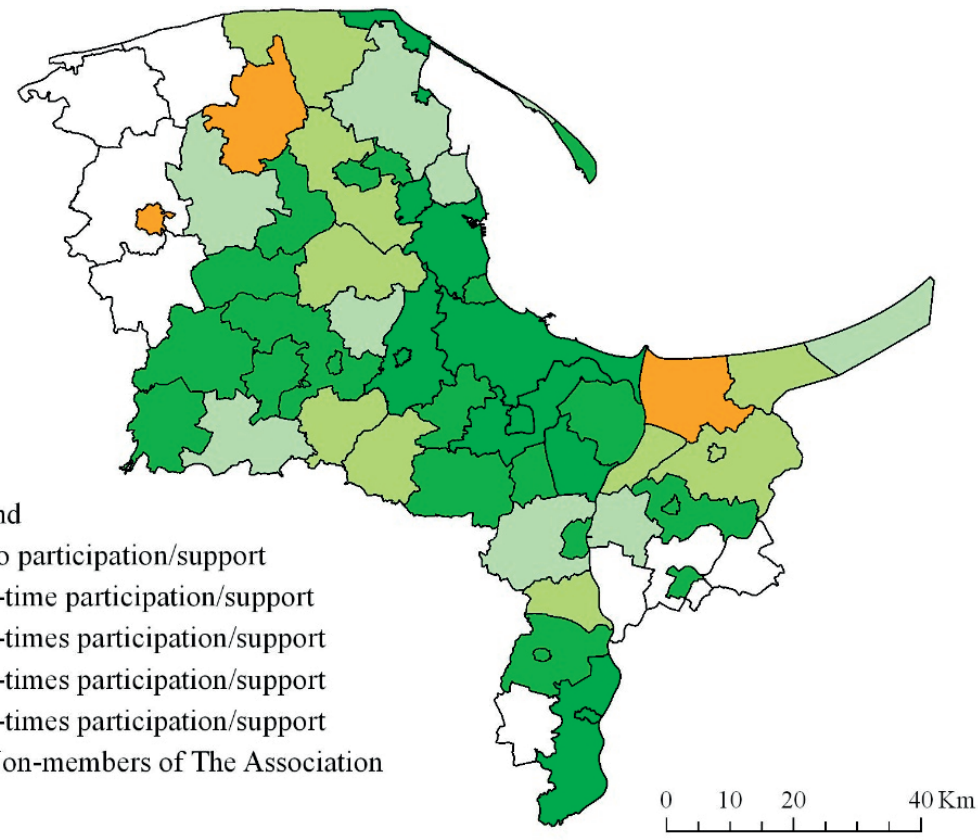

Map 2. Representatives of communities towards the idea of establishing a metropolitan union in Pomeranian Voivodeship. Participation in proceedings of the General Assembly of the GGS MA, as well as signing the declaration of support on January 2018 
as evidenced by, among others, the participation of representatives of the local government in a meeting with MPs organized in the Sejm of the Republic of Poland on 18 July 2018. It should be seen as another point in the process of lobbying the central authorities in favour of enacting a law dedicated to the Gdańsk-Gdynia-Sopot Metropolitan Area. ${ }^{7}$

\section{Conclusions}

Referring to the previous considerations, several crucial factors which will strongly influence the scope of metropolitan cooperation within the Gdańsk-Gdynia-Sopot Metropolitan Area in the forthcoming years could be identified. Two of them lie within the scope of responsibilities of entities located in the area. They are durability of collaboration mechanisms being developed during the implementation of projects under the Integrated Territorial Investment mechanism and their financing in the next EU programming period, as well as the capability of leaders' developing (or in some places beginning) the cooperation in the common interest of the all local governments and inhabitants of the area. The other factor is the shape of policies of the central government and parliament regarding the establishment of a metropolitan union in the area, and thus, a financial guarantee of activities carried out on a metropolitan scale regardless of the EU fund streams.

In the diagnosis developed during the work on the Strategy (at the time) of the Gdańsk Metropolitan Area (2015), it was strongly recommended to "establish a onemetropolitan cooperation forum by integrating the GOM and NORDA Forum communities (to create a union or an inter-municipal association analogous to the Upper Silesian Metropolitan Union)” (Brodzicki et al., 2014: 109). To the pleasant surprise of the authors of this document, it happened not much later than the publishing of the diagnosis. However, a number of recommendations have not been implemented yet, or have only been taken under consideration partially. Among others, this applies to: defining the target areas of metropolitan cooperation on the basis of explicit declarations of individual actors, accepting the target level of cooperation in particular areas, as well as approving the operational programmes to implement the GGS MA strategy by the authorities.

The entity with the stronger mandate to provide public tasks on a metropolitan scale would certainly be able to bring the matter to an end more effectively, which was succinctly described by Sagan and Canowiecki, concerning activities of a similar nature. Using their characteristics, the existing Gdańsk-Gdynia-Sopot Metropolitan Area Association - although one cannot underestimate the importance of its functioning and

\footnotetext{
7 As Paweł Adamowicz, Mayor of Gdańsk, said: "We will continually, in this and the next years, push for accepting by Polish Parliament (elected for the current or the next term) the law dedicated to our metropolitan area" (source: https://www.gdansk.pl/wiadomosci/Chcemy-metropolii-na-Pomorzu-Deklaracjasamorzadow-i-spotkanie-z-parlamentarzystami,a,119465, access: 30.07.2018).
} 
the implementation of activities involving several dozen local governments - remains, however, merely "an administrative body with competences of management, decisionmaking and control." A stronger authority would certainly be the metropolitan union - "an organization acting as the initiator and catalyst of activities - a platform for cooperation equipped with legislative instruments, as well as having the opportunity to support the implementation of joint, multi-objective competences financially" (Sagan \& Canowiecki, 2011: 59).

In the context of the above conditioning, the impact of specific activities carried out by the Association on the construction of a metropolitan community should not be underestimated either. As Amin and Thrift indicate, one can often underestimate the meaning of infrastructure as a tool of political actions and influence (2017: 6). Nelles et al. prove in turn that the central role in the political construction of the metropolitan dimension and given activities relies first and foremost upon the engagement of public authorities, not the other entities (2018). Primarily, the project of The Metropolitan Bike System - a public-led initiative - has a chance to increase the recognition of the Association among residents significantly, and positively affect the social perception of the benefits of metropolitan cooperation. It will be implemented in 14 communities, starting from November 2018, when $30 \%$ of the planned pool of over 4,000 pool has been made available. A full metropolis-wide rollout is planned for March $2019 .{ }^{8}$ If the project turns out to be a success, it may become a landmark similar to the Pomeranian Metropolitan Railway, which significantly brought Kashubian region and the core of the metropolitan area closer to each other.

\section{References}

Amin A., Thrift N., 2017, Seeing like a city, Polity Press, Cambridge (UK).

Barnett C., Bridge G., 2016, “The Situations of Urban Inquiry: Thinking Problematically About the City”, International Journal of Urban and Regional Research, vol. 40, p. 1186-1204.

Brenner N., 1999, "Globalisation as Reterritorialisation: The Re-scaling of Urban Governance in the European Union", Urban Studies, vol. 36, No. 3, p. 431-451.

Brenner N., 2001, “The Limits to Scale? Methodological Reflections on Scalar Structuration”, Progress in Human Geography, vol. 25, No. 4, p. 591-614.

Brodzicki T., Gawlikowska-Hueckel G., Komornicki T., 2014, Opracowanie Strategii Rozwoju Gdańskiego Obszaru Metropolitalnego do 2030 roku. Diagnoza ogólna stanu rozwoju obszaru metropolitalnego, Gdańsk.

Combees M., 2014, "From City-Region Concept to Boundaries for Governance: The English Case”, Urban Studies, vol. 51, p. 2426-2443.

Czepczyński M., 2014. “The Making of the Gdańsk Metropolitan Region. Local Discourses of Powers, Identities and Hopes". Quaestiones Geographicae, No. 33(4), p. 57-66.

D’Albergo E., Lefèvre Ch., 2018, “Constructing Metropolitan Scales: Economic, Political and Discursive Determinants”, Territory, Politics, Governance, vol. 6, No. 2, p. 147-158.

\footnotetext{
8 Sources: http://www.metropoliagdansk.pl/mevo/ (access: 1.08.2018) and https://www.gdansk.pl/ wiadomosci/MEVO-Umowa-z-Nextbike-Polska-podpisana-W-listopadzie-wsiadziemy-na-rowermetropolitalny,a,117468 (access: 1.08.2018).
} 
Danielewicz J., 2013, Zarządzanie obszarami metropolitalnymi wobec globalnych procesów urbanizacji, Wydawnictwo Uniwersytetu Łódzkiego, Łódź.

Deas I., 2013, "The Search for Territorial Fixes in Subnational Governance: City-Regions and the Disputed Emergence of Post-Political Consensus in Manchester, England”, Urban Studies, vol. 51, p. 2285-2314.

Delaney D., 2016, "Legal Geography III: New Worlds, New Convergences", Progress in Human Geography, vol. 41, No. 5, p. 667-675.

Dembski S., 2015, "Structure and Imagination of Changing Cities: Manchester, Liverpool and the Spatial in-Between”, Urban Studies, vol. 52, p. 1647-1664.

Fricke C., Gualini E., 2018, "Metropolitan Regions as Contested Spaces: The Discursive Construction of Metropolitan Space in Comparative Perspective”, Territory, Politics, Governance, vol. 6, No. 2, p. $199-221$.

Harrison J., 2013, "Rethinking City-Regionalism as the Production of New Non-State Spatial Strategies: The Case of Peel Holdings Atlantic Gateway Strategy”, Urban Studies, vol. 51, p. 2315-2335.

Heihsohn K., 2014, Can We Survive Without Immigration, Smart Metropolia Congress, Gdańsk.

Herrschel T., Newman P., 2002, Governance of Europe's City Regions Planning, Policy E Politics, Routledge, London.

Integrated Territorial Investment, Cohesion Policy 2014-2020, 2014, European Commission paper.

Jonas A.E.G., Moisio S., 2018, “City Regionalism as Geopolitical Processes. A New Framework for Analysis”, Progress in Human Geography, vol. 42, No. 3, p. 350-370.

Kaczmarek T., Mikuła Ł., 2007, "Metropolitan Areas in Poland: Towards a New Scale of Urban Governance?”, Quaestiones Geographicae, vol. 26B, p. 97-105.

Kauffmann A., 2016, “Is the 'Central German Metropolitan Region' Spatially Integrated? An Empirical Assessment of Commuting Relations”, Urban Studies, vol. 53, p. 1853-1868.

Keating M., 2017, “Contesting European regions”, Regional Studies, vol. 51, p. 9-18.

Keil R., Hamel P., Boudreau J.-A., Kipfer S., 2016, Governing Cities Through Regions: Canadian and European Perspectives, Wilfrid Laurier University Press, Waterloo (Canada).

Kowalewski A.T., 1991, “Trudne początki samorządu terytorialnego”, Samorząd Terytorialny, No. 1-2, p. 95-103.

Krukowska J., Lackowska M., 2016, “Metropolitalne kolory europeizacji. Instytucjonalizacja współpracy w funkcjonalnych obszarach miejskich w Polsce w świetle nowych instrumentów polityki spójności UE”, Studia Regionalne i Lokalne, No 1(63), p. 82-107.

Kübler D., 2018, "Citizenship in the Fragmented Metropolis: An Individual-Level Analysis from Switzerland”, Journal of Urban Affairs, vol. 40, No. 1, p. 63-81.

Lackowska M., 2007, "Metropolitan Governance in Poland - Is Voluntary Cooperation Condemned to failure?" In: Erling Klausen J., Swianiewicz P. (eds), Cities in City Regions: Governing the Diversity, European Urban Research Association, Warszawa, p. 133-156.

Lackowska M., 2009, Zarządzanie obszarami metropolitalnymi w Polsce. Między dobrowolnościq a imperatywem, Wydawnictwo Uniwersytetu Warszawskiego, Warszawa.

Lackowska M., Mikuła Ł., 2018, "How Metropolitan Can You Go? Citizenship in Polish City-Regions”, Journal of Urban Affairs, vol. 40, No. 1, p. 47-62.

MacLeod G., Goodwin M, 1999, "Space, Scale, and State Strategy: Rethinking Urban and Regional Governance”, Progress in Human Geography, vol. 23, p. 503-527.

Neuman M., Hull A., 2009, “The Futures of the City Region”, Regional Studies, vol. 43, No. 6, p. 777-787.

Nelles J., Gross J.S., Kennedy L., 2018, “The Role of Governance Networks in Building Metropolitan Scale”, Territory, Politics, Governance, vol. 6, No. 2, p. 159-181.

Niziołek M., 2008, Problemy ustroju aglomeracji miejskich, Wolters Kluwer Polska, Warszawa.

Programowanie perspektywy finansowej 2014-2020. Umowa partnerstwa, 2017, Ministerstwo Infrastruktury i Rozwoju.

Pyka R., 2016, "Metropolizacja bez metropolii. Perspektywy upodmiotowienia polskich obszarów metropolitalnych na przykładzie konurbacji górnośląskiej”, Górnośląskie Studia Socjologiczne. Seria Nowa, vol. 7, p. 117-137.

Regulski J., 1991, “Samorząd terytorialny: skąd i dokąd?”, Samorząd Terytorialny, No. 1-2, p. 104-108. 
Sagan I., Canowiecki Z., 2011, Między integracją a konkurencją. Gdańsko-Gdyński Obszar Metropolitalny, Wydawnictwo Naukowe Scholar, Warszawa.

Smętkowski M., Gorzelak G., Kozak M., Olechnicka A., Płoszaj A., Wojnar K., 2011, The European Metropolises and Their Regions: from Economic Landscapes to Metropolitan Networks, Wydawnictwo Naukowe Scholar, Warszawa.

Statut Stowarzyszenia Obszar Metropolitalny Gdańsk-Gdynia-Sopot uchwalony dnia 13 kwietnia 2015 r., ze zm. z dnia 8 czerwca 2017 r.

Strategia Obszaru Metropolitalnego Gdańsk-Gdynia-Sopot, 2015, Gdańsk.

Suliborski A., Przygodzki Z., 2010, Łódzka metropolia. Problemy integracji społecznej i przestrzennej, Wydawnictwo Biblioteka, Łódź.

Swianiewicz P., 2002, "Size of Local Government, Local Democracy and Efficiency in Delivery of Local Services - International Context and Theoretical Framework” In: Swianiewicz P. (ed.), Consolidation or Fragmentation?: The Size of Local Governments in Central and Eastern Europe, Central European University Press, Warszawa, p. 5-29.

The Metropolitan Unions Law of 9 October 2015 (Journal of Laws of the Republic of Poland 2015, pos. 1890).

Szajnowska-Wysocka A., Zuzańska-Żyśko E., 2013, “The Upper-Silesian Conurbation on the Path Towards the 'Silesia' metropolis”, Bulletin of Geography. Socio-Economic Series, No. 21, p. 111-124.

The Slaskie Voivodship Metropolitan Union Law (Journal of Laws of the Republic of Poland 2017, pos. 730).

Vallbé J.-J., Magre J., Tomàs M, 2018, “Being Metropolitan: The Effects of Individual and Contextual Factors on Shaping Metropolitan Identity, Journal of Urban Affairs, vol. 40, No. 1, p. 13-30.

Ziafati Bafarasat A., 2018, “'Theorizing' Regime Theory: A City-Regional Perspective”, Journal of Urban Affairs, vol. 40, No. 3, p. 412-425.

Zuzańska-Żyśko E., 2016, Procesy metropolizacji. Teoria i praktyka, Wydawnictwo Naukowe PWN, Warszawa.

\section{Websites}

www.metropoliagdansk.pl

www.gdansk.pl 